\title{
APUNTES DE "LA CIUDAD PODRIDA": LA CONFIGURACIÓN DISTÓPICA DE LA HABANA EN LA POESÍA DE ÁNGEL ESCOBAR
}

\author{
María Lucía Puppo
}

\begin{abstract}
It has been argued that Ángel Escobar's (1947-1997) poetry rejects a referential connection with real space, like most Cuban poets whose first important works appeared in the 1980s. Yet several strategies that configure a polyvalent and dystopian image of Havana can be traced throughout Escobar's books. I propose an analysis of the logics of spatial syntax in the author's poetics, taking into account the rhetoric and thematic repertories associated to urban space, as well as the references to the visual arts and the main isotopies that converge upon the representation of the "filthy" and "rotten city" of the end of the century.
\end{abstract}

Keywords: Ángel Escobar, Cuban poetry, 1980, city, referent, dystopia

\section{RESUMEN}

Se ha señalado que la poesía de Ángel Escobar (1947-1997) no guarda un vínculo referencial con el espacio real, como ocurre con la mayoría de los autores cubanos que publican sus primeras obras importantes hacia 1980. Sin embargo este trabajo propone un rastreo de diversas estrategias que, en los sucesivos libros de Escobar, configuran una imagen polivalente y distópica de La Habana. Se analizará la lógica que gobierna la sintaxis espacial en el sistema poético de este autor, teniendo en cuenta los repertorios retóricos y temáticos asociados al espacio urbano, así como los contactos con las artes visuales y las principales isotopías que convergen en la representación de "la ciudad sucia" y "podrida" de fin de siglo.

Palabras clave: Ángel Escobar, poesía cubana, 1980, ciudad, referente, distopía

\section{RÉSUMÉ}

On a signalé que la poésie d'Angel Escobar (1947-1997) ne garde pas de lien référentiel avec l'espace réel, comme c'est le cas pour la plupart des écrivains cubains publiant vers 1980 leurs premières œuvres significatives. Il existe pourtant dans les livres d'Escobar des stratégies configurant une image polyvalente et dystopique de La Havane que cet article cherche à déterminer. On analysera la logique qui gouverne la 
syntaxe spatiale du système poétique de l'auteur, en tenant en compte des répertories rhétoriques et thématiques associés à l'espace urbain, tout comme les contacts avec les arts visuels et les principales isotopies contribuant à la représentation de «la ville sale» et «pourrie» de la fin de siècle.

Mots-clés: Ángel Escobar, poésie cubaine, 1980, ville, référent, dystopie

Recibido: 5 julio 2010 Revisión recibida: 22 abril 2011 Aceptado: 25 abril 2011

\title{
1. Un lugar incómodo
}

\author{
... hablo de la ciudad inmensa, realidad diaria hecha de dos \\ palabras: los otros. \\ Octavio Paz
}

Porque sé demasiado de las calles que envenenan mi sangre.

Ángel Escobar

Pon su Castillo del Morro, su mar y su malecón infinito, la ciudad de La Habana ha generado una mitología literaria desbordante, que abarca desde los velados "paisajes del trópico" de Julián del Casal hasta las ruinas habitadas que describe la prosa de Antonio José Ponte, en donde aún puede reconocerse el señorío criollo del Vedado que amó Dulce María Loynaz y el ritmo de los sones mulatos que reprodujo el verso de Nicolás Guillén.

Leonardo Padura (2006) ha destacado el rol fundamental que tuvo la fijación narrativa de la imagen de La Habana, en el siglo XIX, para la creación de un espacio nacional. Con su novela Cecilia Valdés o la Loma del Ángel (1882), Cirilo Villaverde ofreció "la primera imagen polivalente" de la ciudad, convirtiéndola de ese modo en "el escenario más complejo y representativo de la nación en la literatura cubana" (Padura Fuentes 2006:42). El proceso de creación de una imagen integrada y definida de la ciudad culmina con la literatura fraguada entre las décadas del 40 y el 50 del siglo recién pasado, período en que se gestaron los relatos de Lino Novás Calvo y El acoso (1956) de Alejo Carpentier.

Las calles habaneras son las auténticas protagonistas de tres grandes novelas de la década del 60: Tres tristes tigres (1967) de Guillermo Cabrera Infante, Paradiso (1966) de José Lezama Lima, y De dónde son los cantantes (1967) de Severo Sarduy. Cada uno de estos textos polifónicos, de factura experimental y exuberancia barroca, prefigura y al mismo tiempo cuestiona la mitificación simbólica que propondría Carpentier en La ciudad de las columnas (1970) (Puppo 2008:74, Aínsa 2006:168). 
Si a partir de la revolución cubana existe cierta literatura que busca preservar una imagen coherente y sólida de la ciudad y la nación, desde fines de los 80 se anuncia la desintegración física y moral que atraviesa cada página de Antes que anochezca (1992) y El color del verano (1991), de Reinaldo Arenas (Padura Fuentes 2006:48). Tras el derrumbe definitivo del imperio soviético, las narraciones de la década de 1990 escritas en la isla trasuntan el clima angustiante del denominado "Período especial en tiempos de paz". En palabras de Rafael Rojas,

A partir de 1992 reaparecieron todas Las Habanas que la revolución se propuso barrer [... :] la última La Habana criolla y colonial, que describió en sus crónicas Julián del Casal, La Habana republicana, neoclásica, que aparece en las novelas de Miguel de Carrión, Carlos Loveira o José Antonio Ramos, La Habana céntrica, de dril cien, sombrero de pajilla y pordioseros en las esquinas, que se ve en las fotos de Walter Evans para The Crime of Cuba, de Carleton Velas, o en páginas de Enrique Labrador Ruiz, Alfonso Hernández Catá y Alejo Carpentier, La Habana de la década de 1950, la de Vedado y Miramar, la de Meyer Lansky, Graham Greene y Guillermo Cabrera Infante y hasta La Habana de los primeros años de la Revolución, en la que los espacios del glamour republicano - mansiones, hoteles, clubes, jardines, parques y playas - eran ocupados por jóvenes barbudos que bajaban de la sierra. (Rojas 2007: s/n)

Cada reinvención literaria de la ciudad conjuga una amalgama de motivos, tópicos y símbolos provenientes de distintos discursos (arquitectónicos, urbanísticos, históricos, políticos, turísticos) que convergen en el imaginario urbano (Álvarez-Tabío Albo 2000). La Trilogía sucia de La Habana (1998) de Pedro Juan Gutiérrez consolidó el paradigma de un subgénero que abunda en visiones nocturnas del deterioro, donde el paisaje caótico de la ciudad deviene en el Apocalipsis cotidiano de personajes tristes y marginales. En esta serie se insertan otros tantos relatos y ensayos desencantados de Zoe Valdés, Abilio Estévez, Luis Manuel García, Miguel Mejides, Iván de la Nuez y Edmundo Desnoes. El predominio espacial del tejido narrativo alberga las vivencias íntimas que exploran dos novelas premiadas de la última década: Bajo la luna negra (2002), de Ernesto Santana, cuenta las últimas horas de vida de un joven enfermo de sida, y Desde los blancos manicomios (2008), de Margarita Mateo Palmer, ofrece una crónica de los últimos años del siglo XX a través de la mirada desopilante de una interna.

El panorama de la poesía no resulta ajeno a las transformaciones en el modo de percibir y describir la ciudad que denota la ficción narrativa cubana. Basta pensar en la continuidad macrotextual que se establece entre las obras poéticas y narrativas de aquellos autores que abordaron asiduamente ambos géneros, como es el caso de Lezama Lima y Virgilio 
Piñera. Este último autor es un referente indiscutible en la plasmación de una imagen fea y hostil del espacio nacional. Con la publicación de La isla en peso (1943), Piñera marcó un hito en la instauración de un discurso escatológico y maldiciente en la poesía. Esta tradición "sucia" perpetuaba a su modo el llamado engagé a la impureza propuesto por Pablo Neruda, cuya fórmula fue asumida en la isla por Nicolás Guillén, el Poeta Nacional de la Revolución.

Si gran parte de la poesía cubana escrita en los años 60 y 70 asumió el ideario político con esperanzado fervor y no poca autocomplacencia, en la década del 80 se observa un cuestionamiento de la idea de nación revolucionaria (Alemany Bay 2008). Los espacios de la isla y la ciudad son evocados desde el humor y la ironía, pero también desde la gravedad y el miedo, como lo prueban los títulos Animal civil (1987), de Raúl Hernández Novás, y Con el terror del equilibrista (1988), de Damaris Calderón. Específicamente la tradición lírica de lo abyecto fue reivindicada, ya en clara disidencia con las voces oficiales, por los versos húmedos y "sin nación" de José Kozer (Arcos 2001:VI), y posteriormente, por la poesía "tortuosa, inclemente, suicida" de Ángel Escobar (Rodríguez Santana 2002:8).

Suciedad, putrefacción y detritus son los materiales privilegiados por Ángel Escobar (Sitiocampo, Guantánamo, 1957 - La Habana, 1997), autor de una poesía "desesperada" y, al mismo tiempo, "anhelante de transparencia, de conocimiento" (Sainz 2006:6). En el lenguaje lúdico e irónico que modula su obra convergen el compromiso social, las grandes preguntas (filosóficas, políticas, estéticas) y las desdichas de la mitología personal: la miseria y el terror experimentados en la infancia, la muerte de la madre a manos del padre, la marginación por ser negro, la esquizofrenia que finalmente derivó en el suicidio del poeta.

La crítica coincide en señalar tres etapas de la trayectoria poética de Escobar (Aguilera 2001, Arcos y Rodríguez Santana 2007). Si los primeros libros fueron bienvenidos y saludados con distinciones por la UNEAC, detrás de su lirismo sencillo ya se advierte un distanciamiento del coloquialismo que imperaba en gran parte de la poesía producida en la Isla hacia los 70 (Sainz 2009:47). A partir de La vía pública (1987), la poesía de Escobar se instaló "en el terreno de la total transgresión" (Papasmatíu 2006:435). Hallamos en este libro los signos de un lenguaje propio que irá afianzándose en las obras de la década de 1990, hasta culminar en la síntesis trágica del poemario Abuso de confianza (1992), una cruenta indagación acerca de la violencia en sus distintas formas. Finalmente, la tercera etapa de la poesía de Escobar se inicia con el poemario Cuando salí de La Habana (1996), texto que expresa una "rara mezcla entre lucidez y alucinación" (Arcos y Rodríguez Santana 2007:64). Esta dualidad se acentúa en el horizonte caótico donde se 
instalan las dos colecciones póstumas, El examen no ha terminado (1997) y La sombra del decir (1997).

Versos como los que afirman "... En la celda de mí, / nada pueden quitarme, nada darme" y "Hoy salí, salgo y saldré de mí" ponen de manifiesto la importancia de la dimensión espacial en la poesía del autor guantanamero, que posiblemente esté relacionada con las alteraciones de la percepción y las experiencias corporales anómalas características de la esquizofrenia (Dykstra 2009). Los principales estudiosos de la obra de Escobar han recalcado que sus poemas nos sitúan "en un extraño afuera ... desde el cual se contempla lo real" (Sainz 2009:46), pues se trata de una poesía "que parece desmentir la inocente exterioridad" (Rodríguez Santana 2006:441). En este sentido el poeta responde a una consigna generacional según la cual "los poetas de los 80 manifiestan sin pudor su necesidad de alejarse del espacio real" (Alemany Bay 2000:95).

Ahora bien, ese distanciamiento del sujeto poético de una referencialidad externa o meramente descriptiva coincide por otra parte con la voluntad de recorrer y volcar en el papel su experiencia de "la ciudad podrida" (Escobar 2006:402). En la imagen distópica del espacio urbano que configuran los textos poéticos de Escobar confluyen estrategias poéticas de distinto orden, vinculadas con figuras retóricas, repertorios temáticos, intertextos y contactos intersemióticos que refuerzan el predominio de un imaginario angustioso y maloliente. El objetivo de este trabajo es trazar algunas coordenadas que determinan el mapa de esa conflictiva relación que une al sujeto poético con La Habana, ciudad elegida por el autor para vivir y morir. Nuestra lectura se centrará en los poemarios más urbanos de Escobar, que comprenden los volúmenes La vía pública (1987), Malos pasos (1991), Todavía (1991) y Cuando salí de La Habana (1997). Este corpus básico se verá complementado por el ya mencionado Abuso de confianza (1992), que reúne varios poemas que reflejan el impacto de una estancia en Chile, y por los dos libros inéditos a la muerte del autor, que presentan un discurso menos lógico $\mathrm{y}$ referencial que los anteriores.

\section{La sintaxis antagónica de los espacios. Arquitectura y claustrofobia.}

Desde el punto de vista de la antropología del imaginario, la obra del poeta guantanamero recurre a dos regímenes de imágenes. Por un lado, hay numerosos poemas que se estructuran en torno a lo que Gilbert Durand (2005) llama el "régimen diurno", asociado al reflejo postural y al dinamismo del ascenso y la caída. Esto resulta evidente en los textos que exploran figuras del vuelo, ya sea exitoso o fallido, como es el caso del papalote o el ángel. Por otro lado, la poesía de Escobar 
se inscribe en el "régimen místico" del imaginario, vinculado con la dominante digestiva y puesto de relieve por acciones como poseer y penetrar. Aquí cobran relieve las entradas del Yo poético a recintos cerrados y, de manera metafórica, su ingreso al cuerpo del poema o al de la mujer amada.

$\mathrm{Al}$ antagonismo inicial entre las dos dinámicas del imaginario se suma otra oposición que es propia de la cultura occidental: la ciudad y el campo. La aldea natal, Sitiocampo, es el punto de partida y también de regreso en la trayectoria vital del hablante poético: "Sitiocampo es un sitio adonde he de llegar" (p. 342). La idealización de la vida sencilla en el bohío, en contacto con la naturaleza, es un tema frecuente en los poemarios de la madurez ("campo joven y ansia", p. 405), donde se la recuerda con nostalgia:

... Vuelve siempre

a tu lar: eres él también; un día

lo sabrás... (p. 374)

Si el anhelo de "lo vegetal" (p. 385) es tan fuerte en el poeta adulto, también es cierto que la urbe fue la tierra prometida de su infancia, ciudad "que es siempre inalcanzable, de otros" (p. 184). Ciertos poemas que poseen un fuerte sustrato autobiográfico revelan que llegar a la ciudad — primero Guantánamo, luego La Habana- significó un salto cualitativo en la vida del escritor, quien sin embargo nunca abandonaría del todo la sensación de ser un provinciano, un marginal. Como lo afirma en un calambur, su estatuto es el de alguien "pobre y feroz, siempre en la periferia” (p. 429).

Ya los títulos de los cuatro poemarios que constituyen el corpus primario de este trabajo remiten a una clave urbana. De manera explícita lo hacen La vía pública y Cuando salí de La Habana, que evocan respectivamente la idea de la ciudad como un espacio común y la (im)posibilidad de abandonarla. Para comprender a qué se refieren los títulos Malos pasos y Todavía debemos leer el poema y el prólogo de donde provienen estas expresiones: "Malos pasos" son los que da el sol cuando logra infiltrarse entre el mármol de un hospital habanero (pp. 178-179); "Todavía" hace referencia al eterno presente de "los tres niños solos en la puerta de la ciudad" (p. 184), posiblemente una imagen del recuerdo de lo que vivió el autor junto a dos de sus hermanos.

La ciudad que describen los textos de Escobar se reconoce por sus espacios abiertos y públicos, que incluyen plazas con árboles, el Malecón, las calles del centro o del suburbio. El mar es una presencia avasallante pero benéfica, una enorme "placenta" o "útero" que señala "el regreso" (p. 247). Los que más parecen tener en cuenta el paisaje marino son los "turistas / panza arriba" (p. 168), mientras que los habituales usuarios 
y habitantes de la ciudad - funcionarios, empleados, obreros, artistas, colegialas- suelen ir de prisa, enfrascados en sus ocupaciones.

El hablante poético observa con ironía el esplendor barroco que aún detenta La Habana, "[e]ntre columnas, arcos y orfebrería" (p. 246), aunque elige situarse "en una estrecha callejuela sucia" (p. 273) que puede conducirlo a un bar, un cine o un templo. En la cartografía de la ciudad lee su propia historia, como cuando recuerda a la mujer que conoció en Alamar, "pudridero del mundo":

.......

Fue en un barrio situado en la periferia de Occidente, un barrio

donde hay almendros, edificios feos como decretos, una luz polvorienta, y alegrías y angustias que ya no son de Kierkegaard. Alamar es el nombre del sitio, y el mar le da templanza, si es que eso es posible en el Caribe; el sol se repite en cada piedra y conversar es un sol, una piedra, un designio. ...... (p. 329)

En estos versos el léxico y las imágenes remiten en principio a una estética de lo feo, pero el ritmo y las pausas que aíslan ciertas palabras crean un efecto poderosamente lírico. De ese modo la monotonía gris del barrio cede ante la musicalidad de su nombre, que a su vez evoca la belleza de una historia de amor.

En la poesía de Escobar se impone una percepción fóbica de los espacios cerrados. Las puertas son metáforas del aislamiento urbano, fronteras hostiles que imposibilitan el pasaje del exterior al interior y viceversa. En un ensayo donde se refiere a un sujeto que está solo y no puede llamarse hijo, Escobar escribe: "la casa se torna entonces en vórtice del conflicto como única realidad ineludible y en germen del terror como suma del miedo a lo naciente ..." (cit. en Sainz 2009:50). Como resultado de una saga familiar terrible, el ámbito doméstico deviene en lo contrario del nido o el hogar. Representa el encierro de la propia conciencia, el infierno interior: "Casa, cuna, cárcel: celda chica, / prisionera de mí" (p. 374).

Por su enfermedad Escobar se vio obligado a pasar numerosos períodos internado. No es difícil imaginar su rechazo hacia las instituciones de salud: "Un hospital es lo que más se asemeja / mejor, igual o más a un hospital" (p. 194). El Yo poético padece en ese ambiente aséptico que parece ahogar toda simiente de color y de alegría. ${ }^{1}$ Mientras un profesional decide y actúa sobre su cuerpo, el "blancor frío" de las paredes obliga al paciente a enfrentar "el helor" de su alma (p. 369). En un contexto alucinatorio el hablante poético convoca la figura de Rimbaud, 
también "amarrado en una cama" (p. 226), y hacia el final de sus días, describe el mundo entero como una enorme "guardería" donde a todos "nos han puesto a dormir" (p. 322).

La claustrofobia que experimenta el sujeto poético dentro de las construcciones se hace extensiva a toda la urbe: "Tragué asfalto" (p. 173); "Es un raudal de velocidad y brillo / sobre los adoquines que pesan en el alma" (p. 315). El asfalto y los adoquines funcionan como sinécdoque de la carga gris que pesa sobre los urbanitas, la fuerza de gravedad que los ata al suelo. Sin negar el dinamismo y la vida cultural que pueblan las calles habaneras, el poeta da cuenta del "egoísmo de la ciudad" (p. 188) que no sabe esperarlo (p. 246). Esta energía que sustenta el movimiento continuo es traducida en La vía pública por la figura del anacoluto, que se repite en cuatro poemas que terminan con el nexo "y", incluido entre ellos el último del libro. El coordinante que no coordina produce en el texto un doble efecto de superposición y vértigo, materializando la sincronía de fragmentos que trasuntan el caos y el sinsentido de todo trayecto.

La lógica azarosa que rige la ciudad es la acumulación, el amontonamiento paulatino de edificios y personas sometidos a los vaivenes del tiempo. El poemario Cuando salí de La Habana abunda en definiciones extáticas para expresar la (in)temporalidad de los espacios:

Viejo mar y desorden del encuentro;

fatiga y ruinas; casas y cosas

que se deshabitan y mienten, perseveran. (p. 281)

Sin la libertad o la esperanza que bien podría introducir el azar, la ciudad se vuelve un plano cambiante pero al mismo tiempo predeterminado, como si se tratara de un tablero donde ya han sido arrojados los dados. El único juego posible para los habitantes consiste en entregarse pasivamente a sus leyes y sus ritmos: "Mi cigarrillo repetido por las calles sucias" (p. 189).

\section{Ut pictura poesis}

La urbe inunda los sentidos del sujeto. Su olor es como el "hedor de trapos rengos, de polvo" (p. 134) y en su territorio "todo huele como a ropa podrida en los estantes" (p. 132). Su sabor invade los recintos ("Si pudiera la boca / desandar el menú de estos espacios", p. 135) y al tacto subsiste "la mano / [...] astillada en el asfalto solo" (p. 136). Su melodía de fondo es el bullicio constante de los autos que cruzan "acezantes" (p. 132), de las guaguas (autobuses) y las personas que circulan por La Rampa (p. 154). En cierta ocasión un sexteto de músicos tocando estremecen el aire de La Habana (p. 246), pero en la ciudad triunfan 
los ruidos que la acercan al pandemonio (Haug 2007): "Vida hecha de chirridos y de antenas—/ videos clips y gritos de fanáticos_-bombas" ;/ [...] /algarabía que a nadie mortifica" (p. 369).

Los ojos son los órganos más heridos en la ciudad que describe Escobar, pues las imágenes desagradables se suceden unas a otras. Un poema de Todavía comienza con esta visión extrañada de las garzas:

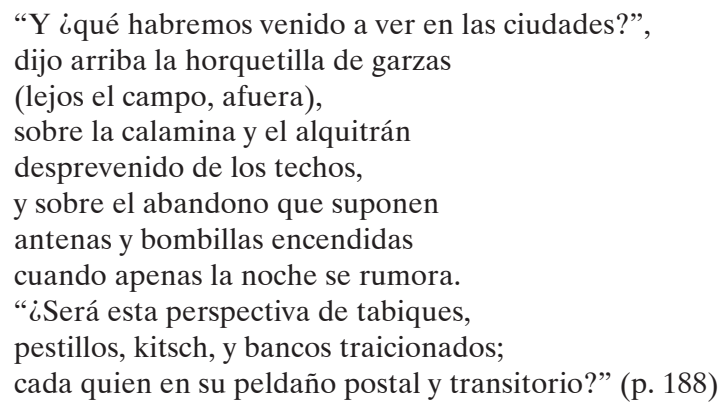

Aquí la improvisación, el abandono, la acumulación kitsch, el individualismo, el encierro y la precariedad de la ciudad son descritos por una mirada ajena a lo humano, la del ave. En su frase inicial vibra un profundo desencanto, que acaso exprese el del poeta provinciano que idealiza "el campo, afuera". Otra escena repugnante se describe en un poema de La vía pública, cuando un artista callejero imagina irónicamente el cuadro que pintaría:

[...] Y la ciudad va y cuelga camisas orinadas rodillas ambidiestras ciegas de pisotones

y un llanto empercudido de preguntas

que no logró blanquear ninguna lavandera.

Eso, al principio; poco a poco, la ciudad cuelga toda.

Pero esta noche el sol no te la seca; sigue.

Y por ahora, siento, seguirá qué colgada. Así es como la veo. (p. 136).

Filtrado por la percepción distorsionada del personaje aparece un motivo que data del pasado colonial, referido a la tarea ejemplar de las lavanderas. Es sabido que por más de dos siglos la ropa limpia colgada en un balcón o una terraza fue símbolo de pulcritud y estatus social en el Caribe. Pero el poema de Escobar no menciona "sábanas blancas" sino "camisas orinadas". ${ }^{2}$ La enumeración se extiende a partes del cuerpo violentadas por otros ("rodillas [...] ciegas de pisotones") y realidades amargas ("un llanto empercudido de preguntas"). En una progresión caótica ya no son estos elementos los que penden de un hilo, sino que es la ciudad entera la que cuelga. Y finalmente hay una inversión del motivo, porque en lugar de secarse al sol, esta ciudad-colgante permanece en la noche. ${ }^{3}$ 
El registro visual tan minucioso de la ciudad denota el interés de Escobar por las artes plásticas, el cine y la fotografía. En su poesía hallamos referencias a los universos pictóricos de los cubanos Nelson Villalobo Ferrer y Antonio Vidal, así como a los graffitis de Basquiat y la cinematografía de Méliès. Ciertas imágenes de sus poemas remiten claramente a una estética expresionista, como es el caso de un perro solo que cruza la calle mordisqueándose "la mugre del pellejo" (p. 133) o de un papalote que "sangra" enredado en los cables del tendido (p. 138). Si el portaligas de una ramera es definido como "la boa constrictora de mi minuto" (p. 280), se dice de un teléfono público que sus números "cuelgan / como ahorcados colgantes" (p. 155).

Dos poemas de La vía pública evocan explícitamente "regiones cubistas". Uno de ellos describe el lecho incómodo de un mendigo que "duerme lejos, detrás del girasol de los paseantes". El otro se centra en la figura que conforman un borracho y su silla, "continuando / la madera que un día también sintió el disgusto / de no poder salir fuera del tronco" (p. 146).

Los textos de Escobar proponen asimismo escenas donde los personajes y el espacio cobran tintes abstractos, al modo de las ambientaciones fantásticas y pesadillescas de Kafka. Así ocurre cuando "el Ajeno" avanza por una acera interminable donde sólo encuentra un cartel que dice "NUNCA" (p. 149). O cuando las puertas se personifican:

Y por eso me dicen transeúnte, porque siempre las puertas me dan con el trasero en pleno rostro.

Mañana yo tendré también alguna

que me cuide este llanto de huérfano abollado

por pedradas que lanza la intemperie,

o pasado mañana no habrá puertas. (p. 150)

La definición del "transeúnte", aquel que se desplaza por la ciudad, no puede ser más desoladora. La personificación de las puertas indiferentes se multiplica en las violentas "pedradas que lanza la intemperie". Todo ello en un estatuto precario y transitorio, pues quién sabe si "pasado mañana no habrá puertas". El tono triste de este hablante contrasta con la actitud desconfiada y agresiva de aquel que rechaza al "prójimo" en la calle porque lo encuentra "oloroso a costumbres que no aguanto" (p. 158). Otro personaje del grupo de los "paranoicos" concluye así su monólogo:

por cuál otra maldita acera caminamos y quién nos estará esperando en la otra esquina - díganmelo señoresqué hacer o no me callo y no se acerque nadie (159)

Resuenan en estos versos los ecos de aquel magnífico comienzo de La isla en peso de Piñera ("La maldita circunstancia del agua por 
todas partes / me obliga a sentarme en la mesa del café"). Sólo que en el universo poético de Escobar el encabalgamiento del verso resulta más violento, el café ha cedido lugar al hospital, y la infusión ha sido catapultada por el cigarrillo y los psicofármacos.

\section{Isotopías urbanas: podredumbre, desintegración y filo}

Un recurso característico de la poesía de Escobar es el oxímoron, figura que propone una coincidentia oppositorum en el verso para provocar un efecto desestabilizador en el lector. Frases como "lo invisible visto" (p. 284) y "lo que digo callando" (p. 410) crean una zona de indecisión semántica e introducen la paradoja en estos "tristes papeles divertidos" (p. 245). Una imagen lindante con el oxímoron que constituye un emblema omnipresente en los poemarios de Escobar es la rosa enferma. Se alude a ella por primera vez en el epígrafe de la segunda sección de La vía pública, que reproduce el primer verso del poema de William Blake, "O Rose, thou art sick!". Síntesis de la belleza fugitiva o terrible, que expresa la crueldad de las cosas buenas y el dolor que causa lo que amamos, esta imagen de la corrupción se relaciona íntimamente con la tendencia de la poesía de Escobar a nombrar lo pútrido y lo sucio. ${ }^{4}$

Para el sujeto poético de Escobar, lo más propio de la ciudad es la podredumbre y la descomposición, factores que constituyen una auténtica isotopía urbana: ${ }^{5}$

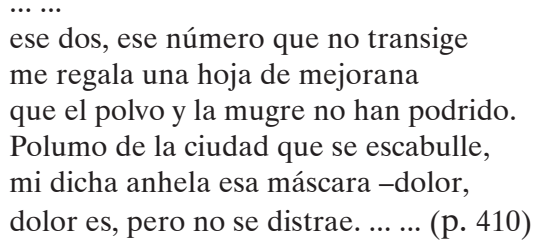

Una hoja, mensajera del mundo natural, apenas resulta una "máscara" para cubrir el dolor humano en medio de la urbe. La síntesis del "polumo", neologismo de Octavio Paz construido sobre la base de los términos "polución" y "humo", aquí reúne "el polvo y la mugre", sinécdoque de una ciudad descuidada y abandonada a su propia suerte. Son incontables los índices lexicales que configuran esta isotopía, al punto que en ella radica una de las principales notas de la poesía de Escobar. Herrumbre, mancha, basura, ácaros, hollín, moho, bacterias, náusea, roña, piltrafa, esperma, vómito, carroña y mierda pululan en los textos del poeta cubano, hasta terminar de perfilar la "ciudad sucia" (p. 251) y "podrida" (p. 402) donde habita el sujeto poético de los tres últimos libros. Por eso no sorprende la recurrencia de un espacio intrínsecamente ligado a lo escatológico: "Un baño. Un baño. / Sólo un baño en la 
nada -este suplicio" (p. 296). También la paradoja alcanza a este recinto, cuya limpieza apenas enmascara el lugar para la defecación: "Cuando antes de morir / escribo todas estas sandeces en la pulcra pared / de un baño público" (p. 229).

Otra isotopía que atraviesa los textos es la desintegración. En principio podemos entender este término en el sentido de decadencia, que incluiría entonces el tópico de la ruina. La poesía de Escobar no esquiva esta imagen cuando describe "un salón con sus arañas últimas" (p. 190), pero no presenta un tratamiento elaborado de las ruinas habaneras finiseculares como lo hace, por ejemplo, la escritura de Ponte (Gómez 2010). Al poeta guantanamero le interesa la metáfora arquitectónica como símbolo de un proceso que afecta tanto a las personas como a su entorno: "Somos aquella ruina que nos consume tanto" (p. 189).

Por otro lado, la isotopía de la desintegración se relaciona con el aislamiento de las personas, la falta de comunicación y la mecanización de la vida social. En tanto centro del poder político, la ciudad es foco de despersonalización, en el plano individual, y de exclusión, en el plano colectivo ("he llegado a la ciudad - / un grito y otro entre edificios y decretos -", p. 301). Sobre el trasfondo de las calles que configuran un "cruel laberinto" (p. 409), el poeta critica duramente el régimen castrista:

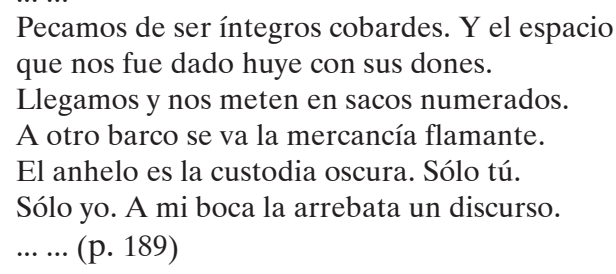

En estos versos hay alusiones más o menos veladas a las polémicas asignaciones de vivienda, la racionalización de alimentos, los aprietos de la economía cubana en los años noventa, la represión estatal y el miedo por parte de la población civil. Ante la parafernalia burocrática de los organismos estatales, el ciudadano es un mero número en un registro, cuyo valor resulta incluso inferior al de los animales: "en la ciudad un carnero / vale más que dos hombres", por eso el sujeto la recorre con la impotencia de una "res destazada en los mercados" (p. 301).

La tercera isotopía que recorre la poesía de Escobar es la del filo. Como bien lo ha expresado Francisco Morán, la lectura de este autor "produce cortaduras" (2008:383). Se trata de una "escritura tasajeada", que acumula hachas, punzones, guillotinas y espejos rotos para volverse cada vez más aguda y potente. En La sombra del decir el sujeto poético percibe el filo como su hábitat ("Vivo en la punta de un cuchillo", p. 373) y llega a identificarse con esta imagen ("Si yo no fuera un cuchillo", 
p. 380). En la misma constelación semántica se leen las partes rotas pedazo, triza, despojo, piltrafa- que desembocan en "la noche hecha añicos" (p. 403). El espacio urbano representa, como la hoja del arma blanca, un juego de espejos perverso, la "infernalización de lo idéntico" que concentra el frío y la intemperie (p. 254). Por analogía con el metal, el hablante poético funciona como un espejo que refleja el rostro de la ciudad al mismo tiempo odiada y amada:

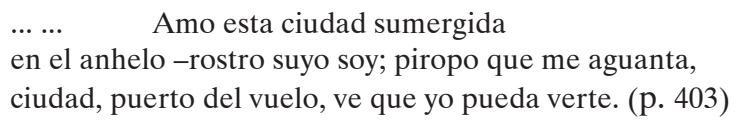

En los textos finales de Escobar crece la violencia del ritmo, las imágenes y el léxico vinculados con la temática urbana. La sinestesia confunde las percepciones de los sentidos ("Veo el sonido de la luz sobre el asfalto", p. 379) y no falta la mención de un "baldío roto" que evoca las descripciones distópicas de T. S. Eliot (p. 343). Las constantes referencias a la podredumbre, la desintegración y el filo mortal resultan tres maneras complementarias de explorar el imaginario fúnebre. De ese modo la ciudad se termina de perfilar como un gran cementerio en el que el poeta se ha declarado prematuramente muerto (p. 416).

\section{Conclusiones}

Los arquetipos, las formas en mí orinan, defecan, se atortojan.

Ángel Escobar

La poesía de Escobar propone un sistema espacial en el que la idealización del campo, su Sitiocampo natal, se opone a la ciudad sucia y podrida que habita el sujeto. La topofobia de la que hablaba Bachelard (1992) se manifiesta tanto en la representación de las calles ruidosas, saturadas de asfalto, como en las imágenes de espacios cerrados opresivos. Para dar cuenta de su desagrado y su furia, el hablante poético se sirve de estrategias retóricas tales como anacolutos, enumeraciones, sinécdoques, personificaciones, oxímoros y sinestesias, e incluso recurre a dos figuras de dicción cercanas al anagrama, el calambur y la palabramaleta.

En los textos analizados La Habana se confirma como "espacio infeliz”, fórmula con la que Hernán Neira (2004) sintetiza la percepción ficcional y real de la ciudad contemporánea. Los motivos tradicionales referidos al espacio urbano (la cárcel, la ruina, el laberinto, el infierno, el cementerio) son apropiados por el discurso renovador de Escobar que los integra al juego constante de alusiones, parodias y contactos interdiscursivos con las artes visuales. Su influencia no tardó en hacerse notar 
en otras poéticas que privilegian un locus de enunciación urbano, como es el caso de La Quinta de los Molinos (2000) de Nancy Morejón, donde se incluye un poema-homenaje al poeta suicida. Entre sus coetáneos y especialmente entre los autores más jóvenes de Cuba, la poesía de Escobar abrió caminos hacia nuevas concepciones del poema y sus posibles vínculos con el espacio habanero. La velocidad de su verso subsiste en las afirmaciones sentenciosas de Odette Alonso ("Esta ciudad se cae y a nadie le interesa. / Atrás se queda el mar / el mar es una lástima de azul desperdiciado") y en la ironía contemporánea de Teresa Melo ("Yo también fui pensada para turistas esta mañana").

Haciendo referencia a la poesía de los chilenos Óscar Hahn y Gonzalo Millán, Óscar Galindo ha escrito que "si la utopía es panóptica, la distopía es telescópica", pues ofrece "una mirada grotesca y exagerada de la realidad" (Galindo 2004:66). Hemos comprobado que la poesía de Escobar propone un peculiar registro pictórico de la ciudad, donde la semiosis espacial opera principalmente a través de la distorsión de los seres y objetos cotidianos en clave expresionista, cubista y onírica. El discurso hiperbólico del poeta guantanamero revela los aspectos grotescos de la cotidianeidad urbana, como lo señaló Daniel Balderston (1990) a propósito de la escritura de Piñera. En los sucesivos libros de Escobar va intensificándose la presencia de lo siniestro en el sentido freudiano de Unheimlich, es decir, de lo cotidiano o familiar que de pronto resulta extraño (Albiac 1995).

Las isotopías de la putrefacción, la desintegración y el filo inscriben la representación de la ciudad en un universo caótico y amenazante que es el mundo privado del poeta. Aunque busca obsesivamente "la realidad real, / lo real real que incomoda" (p. 380), el Yo de Escobar se reconoce atrapado "en medio de esta ciudad mental en que deliro absorto" (p. 248). La urbe es un monstruo ingobernable, un organismo que se mueve con dos fuerzas antagónicas, una centrípeta y otra centrífuga. Por un lado es la "gran boca" que todo lo engulle y, por otro, es un territorio que expulsa y envenena (p. 253). Otra paradoja radica en las dos caras que la ciudad muestra al sujeto poético, quien la vislumbra como un "desierto" de soledad (pp. 259, 268), o bien como un espacio sobresaturado de signos y objetos: "ni siquiera hallo / una pared, un muro donde poner mi graffiti” (p. 256).

"Y en esta ciudad sucia el futuro es un mero subterfugio" (p. 251), afirma el poeta que se inclina hacia una visión pauperizada e intemporal de La Habana. Abandonar la ciudad es una ilusión, como recuerda el poema de Cavafis, porque el sujeto la llevará siempre dentro de sí, condenado a recorrer las mismas calles. De hecho su destino obligado es buscar la ciudad y la utopía, idea con la que parece concluir un poema de Cuando sali de La Habana: 


\begin{abstract}
No has logrado escapar. Todo viene
y se transforma en dádiva o mandato. La sonrisa

del otro también es la sonrisa de este ensayo de infierno.

La belleza sigue sentada en las rodillas del raptor -

no hay ciudades esplendorosas: tan sólo como ardid

o argumento o vicio o sed vale buscarlas, y las buscas. (p. 264)
\end{abstract}

Estamos frente a la voz resignada de quien sabe que, incluso en el campo añorado, sentiría "la nostalgia / de pueblos y edificios polvosos venideros" (p. 390). El hablante poético, como el sujeto moderno, se sabe impensable e innombrable al margen de la experiencia urbana. "Todo es la biografía de la ciudad" (p. 280), al punto que el Yo poético se ha hecho uno con ella: "soy basurales y cuchillos deshechos" (p. 391).

En una carta a Alain Sicard, escrita el 15 de octubre de 1993, Ángel Escobar lamentaba el suicidio de su amigo Raúl Hernández Novás, otro notable poeta de la generación de los 80 (Arcos y Rodríguez Santana 2007:54). Menos de cuatro años después el propio Escobar decidió arrojarse al asfalto desde su balcón del cuarto piso. Ese gesto terminó de fundir la poesía y la persona con el espacio habanero, al punto que las palabras que Ángel dirigió a su amigo fallecido hoy se aplican a él mismo: "caminaba por la ciudad y ahora es un signo de ella".

\title{
Notas
}

1 En ese ambiente incoloro y triste, la excepción es la imagen feliz de "tres viejecitos" que bailan, afuera, "dos gracias al rumor de un marcapasos" (pp. 194-195).

2 "Sábanas blancas" (1995) es el título de una famosa canción interpretada por el cantautor popular Gerardo Alfonso. La letra comienza dirigiéndose a la ciudad ("Habana, mi vieja habana / señora de historia de conquistadores y gente / con sus religiones, hermosa dama") y en el estribillo repite "Sábanas blancas colgada [sic] en los balcones".

3 Otra inversión del motivo aparece en el poema "Las puertas", también perteneciente a La vía pública: "El Ajeno se para y ve cómo la noche / sube con una vara sus cordeles / y se mecen chorreando anchas sábanas negras" (p. 150).

${ }^{4}$ La imagen posee una importancia a nivel metapoético que, por 
cuestiones de espacio, no desarrollaremos aquí. Basta señalar que, como la rosa enferma, la poesía de Escobar se sostiene en constante tensión y en un equilibrio muy frágil, pues sus elementos más propiamente líricos (asociados a una profunda búsqueda estética) llevan el germen de su propia de(con)strucción (a través de estrategias como la autocita, el léxico vulgar, el pastiche, la ironía, el humor y la parodia).

5 La isotopía es un concepto básico para la definición de procedimientos en los textos literarios. El semiólogo A.G. Greimas acuñó el término para designar "un haz de categorías semánticas redundantes, que subyacen al discurso que se considera" (Marchese y Forradellas 2000:223).

\section{Referencias}

Aínsa, Fernando. 2006. Del Topos al Logos. Propuestas de geopoética. Iberoamericana-Vervuert: Madrid-Frankfurt am Main.

Alemany Bay, Carmen. 2000. "Poesía cubana de finales del XX: 1980-2000". América sin nombre: 2 (diciembre):92-100.

2008. "Nación y memoria en la poesía cubana de la Revolución". Atenea: 497:23-35.

Aguilera, Carlos Alberto. 2001. "Funny papers. Apuntes sobre la poesía de Ángel Escobar". En Ángel Escobar: el escogido. Textos del coloquio homenaje al poeta Ángel Escobar (1957-1997), compilado por Efraín Rodríguez Santana. La Habana: Ediciones Unión, pp. 137-148.

Albiac, Gabriel. 1995. Caja de muñecas: figuras de la concepción inmaculada. Barcelona: Destino.

Álvarez-Tabío Albo, Emma. 2000. Invención de La Habana. Barcelona: Casiopea.

Arcos, Jorge Luis. 2001. "La poesía de José Kozer: del cachorro doméstico a la vía láctea”. Prólogo a José Kozer, No buscan reflejarse. Antología poética. La Habana: Letras Cubanas, V-XVI.

Arcos, Jorge Luis y Rodríguez Santana, Efraín. 2007. “Cartas sobre dos poetas suicidas. Ángel Escobar y Raúl Hernández Novás”. Encuentro de la cultura cubana: 45-46 (verano/otoño):50-66.

Bachelard, Gaston. 1992. La poética del espacio. México: FCE.

Balderston, Daniel. 1990. "Estética de la deformación en Gombrowicz y Piñera”. Explicación de Textos Literarios 19(2):1-7.

Durand, Gilbert. 2005. Las estructuras antropológicas del imaginario. Madrid: FCE.

Dykstra, Kristin. 2009. "Poems by Ángel Escobar”. In translation (junio). URL: $<$ http://intranslation.brooklynrail.org/spanish/poems-by-angel-escobar>.

Escobar, Ángel. 2006. Poesía completa. La Habana: Ediciones Unión. 
Galindo V., Óscar. 2004. "Distopía y Apocalipsis en la poesía de Óscar Hahn y Gonzalo Millán”. Anales de literatura hispanoamericana 33:65-76.

Gómez, Ivette. 2010. "Simulaciones de la memoria: Antonio José Ponte y Tuguria, la ciudad-ruina”. La Habana Elegante (primavera-verano). URL: <http://www.habanaelegante.com/Spring_Summer_2010/Invitation_Gomez.html\#nota1>.

Haug, Susana. 2007. “Ángel Escobar o los modos de alcanzar el infinito”. La Siempreviva (2).

Marchese, Angelo y Forradellas, Joaquín. 2000. Diccionario de retórica, crítica y terminología literaria. Barcelona: Ariel.

Morán, Francisco. 2008. "Ángel Escobar: la luz sobre el asfalto”. Mandorla, Nueva Escritura de las Américas / New Writing from the Americas 11:382-398.

Neira, Hernán. 2004. La ciudad y las palabras. Santiago de Chile: Editorial Universitaria.

Padura Fuentes, Leonardo. 2006. "La Habana literaria”. Cuadernos Hispanoamericanos 670 (abril):41-50.

Papastamatíu, Basilia. 2006. “Ángel Escobar, el escogido”. Ángel Escobar, Poesía completa. La Habana: Ediciones Unión, pp. 435-437.

Puppo, María Lucía. 2008. "Postales de La Habana: de Dulce María Loynaz a Nancy Morejón”. Nonada Letras em Revista 11:73-90.

Rodríguez Santana, Efraín. 2002. "Prólogo" a Ángel Escobar, Fatiga ser dos sombras. Antología poética. Madrid: Betania.

Rojas, Rafael. 2007. "Todas Las Habanas de Cuba”. PRL on line, 1(1) (setiembre-noviembre). URL: <https://www.revistaprl.com/review. php? article $=2 \&$ edition $=1-1>$.

Saínz, Enrique. 2006. "Prólogo” a Ángel Escobar, Poesía completa. La Habana: Ediciones Unión, 5-9.

2009. "Dos visiones sobre la poesía cubana". Cuadernos Hispanoamericanos 706 (abril):35-58. 